\title{
A FEW NOTES ON THE HISTORY OF LUANGO (NORTHERN PORTION OF CONGO COAST)
}

ThE "Bavili," or the inhabitants of Luango, occupy the coast of Africa between the Mayumba River north and that of the Chiloango River south, that is, the land about latitude $5^{\circ} \mathrm{S}$. The word Bavili might be translated as the lost people, referring, perhaps, to their journeying north from Kongo's Kingdom south of the Congo, or it might be translated as the ripe people in the sense that they complete the trinity of kingdoms, representing the son province in connection with the mother and father provinces, Kakongo and Kongo. So far as we know, these people have not been subject to any great raids, like those of the Bayaka, or the people of the father province. This may be owing to the protection given to them by the belt of forest that divides their country on the east from the country of the Bakunia and Bayaka. There are traditions of wars between the Bavili and the Bakochi, or people of Kakongo, when they say that the Bavili went in such crowds to Kakongo as to have dried up its rivers in the crossing.

It is only by their "Bakichi ba chi" that traces can be found of the provinces having once been under one King, but the King of Kongo is still looked upon as their spiritual head in a far off kind of way, and their system of Government is the same. They are also part of the Fiote people, and recognise the Leopard (Ngo) as their " totem." But when the first missionaries made their appearance in Africa, both Kakongo and Luango acted as if they were independent kingdoms.

We owe the discovery of the Kongo to the enterprise of 
Prince Henry the Navigator, fourth son of John I., King of Portugal, and grandson of Edward III., King of England.

Diego Cao, by royal edict dated 14th April, 1484, was commissioned to extend the explorations on the coast of Africa, and he discovered the Kongo River in 1484. The native name for this river is Zaili, Zairi, or Zaidi, and it was so called as being the way of the spirit, or personality of love and knowledge. The name, of course, was given to it long before it was discovered by Diego Cao, as part of the Fiote religious system, as we shall learn later on. It must not be supposed that because the missionaries of old came that way and taught the natives certain trades that therefore the river was called by this name. The spirits of all rivers in this part of Africa are supposed to teach the Fiote some lesson.

The first expedition arrived at San Salvador in 1491 .

One hundred years later we have a list of the provinces of the King of Kongo's immediate kingdom, given to us by Pisafetta on the authority of the hermit, Duarte Lopez.

The first mention of Luango is of a comparatively late date, i.e., 1663, when Christianity was first brought there by Father Ungaro.

Father Jerome Merolla da Sorrento, I682, says that he never heard there was any Christian prince in the kingdom of Angoyo (Cabinda), that country having been always inhabited by a people extremely given to sorcery and magic. But Barbot, who must have touched at Luango about the year 1700 , says English was spoken in Kabinda at that time, and that the blacks were all Christians.

When the history of Luango and Kakongo by the Abbe Broyart (Paris, 1776), is brought up to date, much use should be made of the old trade books with their accounts of the sale of slaves and trade with the captains of sailing vessels who were in the habit of giving the princes credit and making remarks in these books. Father T. Derouet has collected a great number of facts in this way, and I hope may soon follow up the work of his famous predecessor, thus filling up the interval between the time of the "tree climbing " missionary age and the present-shall we say-intellectual one?

Then the old books of copies of correspondence of the firms 
of the British African Merchants, Taylor and Laughland, and those of Messrs. Hatton and Cookson, would throw light on the following period, when merchants had settled establish. ments.

But while missionaries and explorers have come and gone, it is an interesting fact that the only constant associates of the inhabitants of the country during the last century were the traders, so that when Mr. Stanley and M. de Brazza rediscovered and brought these parts once more within history, they found the traders long established.

In 1873 the German West African Expedition settled in Chinchonso, a place in the country of Samanu, in the kingdom of Luango.

In spite of the work of Du Chaillu, Mr. Bruce Walker, the Marquis de Compeigne, and Monsieur Marche, the Ogowe River remained unknown until, in 1874 , M. de Brazza began his interesting labour in that part of Africa.

I875.-In 1875 De Brazza expressed his anxiety to open up the Ogowe.

1877.-In 1877 Stanley arrived in Boma.

1878. - The Comité d'Etudes du Haut Congo was formed in Brussels.

1879-1882.-De Brazza's voyage to the Congo vid the Ogowe-Brazzaville was carried out, and treaties were made with the Chiefs of Alima and Ntamo. In 1882 De Brazza declared the only practical route between the coast and Brazzaville to be vid the $K u i l u$ River.

1882, November $3^{\text {oth. }}$-The famous Makoko treaty was ratified by the French Parliament.

1883, January Ioth.-De Brazza was appointed Commissionnaire du Gouvernement de la Republique Franca in West Africa.

1883.- Return of missionaries to Luango.

1884, April 23rd.-Colonel Strauch, on behalf of the African International Association, gave France the famous "droit du préférence" on the Congo State.

I885, February 5th.-France, by a treaty with the African International Association (nascent Congo State), gave up its pretensions to the left bank of the Lower Congo, and obtained 
the cession of the territories Niari Kuilu. February 14th.Portugal, with the mediation of France, concluded a treaty with the African International Association.

1885, February 26th.-Berlin Act was signed by which the district of " Congo Français" was acknowledged as French.

Since which time this part of Luango under French rule, and no longer managed by its native rulers, has passed through a somewhat troublous time, which must result in damage to commerce unless the French Government wakes up and takes up the "white man's burden" in earnest, instead of trying to throw it on the shoulders of irresponsible concessionnaires.

R. E. DenNEtT. 